\title{
Patrycja Pałka
}

Uniwersytet Jagielloński w Krakowie

\section{Toponimy w słownikach ogólnych języka polskiego}

\section{Wprowadzenie}

W niniejszym artykule postaramy się odpowiedzieć na pytanie, czy i w jaki sposób nazwy własne, na przykładzie toponimów, winny być opisywane w słownikach ogólnych języka polskiego. Nie jest to problem nowy, lecz wielokrotnie już podejmowany, choćby w pracach K. Rymuta [1988], A. Cieślikowej [1993], W. Chlebdy [2000] czy B. Dereń [2005], jednak nadal ważny i aktualny. O wadze podnoszonej problematyki świadczy niewypracowanie do tej pory spójnej koncepcji opisu nazw własnych w nieonomastycznych i niespecjalistycznych dziełach leksykograficznych. Najpierw ustosunkujemy się więc do problemu wartości semantycznej propriów oraz omówimy obecność toponimów w wybranych XIX i XX-wiecznych słownikach. Następnie zaproponujemy koncepcję opisu leksykograficznego jednostek onimicznych, na przykładzie toponimów, która z jednej strony będzie czerpała z badań z zakresu onomastyki i semantyki językoznawczej, a z drugiej wynikała z analizy tekstów ekscerprowanych z Narodowego Korpusu Języka Polskiego ${ }^{1}$.

\section{O wartości semantycznej nazw własnych - ustalenia teoretyczne}

Nie jest możliwe, aby w tym miejscu przytoczyć i omówić choćby część dyskusji na temat wyróżników proprialności ${ }^{2}$, funkcji nazw własnych ${ }^{3}$, a przede

${ }^{1}$ NKJP to dostępny publicznie, bezpłatnie i online (www.nkjp.pl) zbiór tekstów z XIX i XX w. w języku polskim, reprezentujących różne style i odmiany polszczyzny [zob. Przepiórkowski et al. (red.) 2012].

${ }^{2}$ Istotę onimiczności rozpatruje się zwykle w odniesieniu do czterech kryteriów: 1) zapisu ortograficznego, 2) gramatyki, 3) semantyki i 4) referencji [zob. m.in. Rzetelska-Feleszko 1993; Kaleta 1998].

${ }^{3}$ Onimy pełnią trzy zasadnicze funkcje: nominacyjną, identyfikującą i różnicującą [zob. m.in. Kaleta 1998; Rutkowski 2001 (2002); Rzetelska-Feleszko 1993]. 
wszystkim problemu znaczenia onimów ${ }^{4}$, dlatego też od razu przejdziemy do prezentacji przyjętego w niniejszym artykule stanowiska dotyczącego semantycznej wartości nazw własnych. Stanowisko to jest kluczowe dla podejmowania dalszych decyzji o opisie tych jednostek. Przyjęcie tezy o asemantyczności nazw własnych skutkuje brakiem podstaw do ujmowania onimów w słownikach ogólnodefinicyjnych, których głównym celem jest objaśnianie wyrażeń językowych i ich właściwości. Zasadniczym argumentem wysuwanym tu przeciwko uwzględnianiu nazw własnych w słownikach jest to, że w planie onimicznym nie mają one znaczenia leksykalnego, nie możemy więc opisać ich znaczenia przedmiotowego, bo nie odnoszą się one do pojęcia, lecz bezpośrednio do nazywanego obiektu. Możemy jedynie opisać cechy tego obiektu jako elementu świata rzeczywistego, czyli podać informację zaczerpniętą z wiedzy encyklopedycznej, a nie językowej. Także w planie odonimicznym - przy wtórnych użyciach (tekstowych metaforach i metonimiach) onimów - wiedza ta, jak twierdzą m.in. A. Cieślikowa i M. Rutkowski, pełni rolę podstawową, gdyż nie jest możliwe, aby nazwa własna została użyta w funkcjach pozareferencjalnych bez znajomości odniesienia [Cieślikowa 2006: 52; Rutkowski 2007: 245-246]. Dopiero proces „odrywania się” jednostki onimicznej od prymarnego denotatu (zwłaszcza w wyniku metaforyzacji) może doprowadzić do utworzenia nowej jednostki leksykalnej w postaci apelatywu deonimicznego, który staje się niebudzącym już wątpliwości przedmiotem opisu w słowniku językowym [Rutkowski 2007: 247]. Aby rozwiązać ten problem i mieć podstawę do ujmowania nazw własnych w słownikach ogólno definicyjnych, należy - po pierwsze - przyjąć tezę, że jednostki te znaczą, a ściślej, że w użyciu prymarnym (nie metonimicznym czy metaforycznym) odnoszą się one do świata pojęć, na który składa się kategorialne minimum znaczeniowe typu 'miejsce' czy 'osoba' [zob. Bogusławski 1977: 43]. Po drugie - wyjściem z problemu jest przyjęcie założeń językoznawstwa kognitywnego [zob. m.in. Langacker 1995; Taylor 2007; Bartmiński 2007; Bartmiński (red.) 1993; Tokarski 1988], w myśl których:

1) nie jest istotne rozgraniczenie między wiedzą językową a pozajęzykową, gdyż język nie jest bytem autonomicznym, lecz częścią kultury i bezpośrednio odzwierciedla procesy poznawcze zachodzące w umyśle człowieka;

${ }^{4} \mathrm{~W}$ literaturze przedmiotu dominuje przekonanie, że nazwy własne nie znaczą [m.in. Algeo 1973; Grochowski 1993; Kosyl 1983; Šramék 1999]; spełniają jedynie funkcję referencjalną, posiadają denotację, ale brak im konotacji [zob. Mill 1843], są więc systemowo pozbawione znaczenia leksykalnego. Nie wyklucza to rozważań na temat ich cech konotacyjnych [zob. m.in. Tokarski 1988, 1991], które ujawniają się w tekście w metaforycznych użyciach onimów. Wartości konotacyjne nazwy mają swoje źródło nie w znaczeniu leksykalnym, lecz powstają na fundamencie funkcji, jaką pełni dana nazwa, i treści, które wprost odnoszą się do desygnatu [zob. Cieślikowa 1993]. Z kolei inni badacze twierdzą, że nazwy własne nie tylko mają znaczenie, ale znaczenie to jest o wiele bogatsze od tego posiadanego przez wyrazy pospolite [zob. Kuryłowicz 1956]. Takie podejście wiąże się z utożsamieniem znaczenia z intensją (treścią). Twierdzi się także, że nazwy własne są w sensie logicznym deskrypcjami jednostkowymi [zob. m.in. Lubaś 2003-2004]. 
2) znaczenie, będąc istotą języka, ma charakter holistyczny, wyobrażeniowy, antropocentryczny i jest równoznaczne z konceptualizacją;

3) nie ma podziału na semantykę i pragmatykę, gdyż nie jest możliwe precyzyjne oddzielnie faktów językowych od pozajęzykowych; nie ma więc sensu rozróżniać znaczenia „czysto” systemowego od konkretnego użycia;

4) znaczenie wyrażeń należy badać w odniesieniu do kontekstu i konsytuacji, gdyż rodzi się ono w interakcji;

5) celem opisu semantycznego danego wyrażenia jest ukazanie wszystkich elementów znaczenia słowa: od składników desygnacyjnych po składniki konotacyjne.

Zanim jednak przejdziemy do ukazania, jak powyższe założenia można dostosować do potrzeb i możliwości opisu w słowniku ogólnodefinicyjnym, chcielibyśmy pokrótce omówić to, w jakim zakresie jednostki onimiczne, a zwłaszcza toponimy, są ujmowane w XIX i XX-wiecznych dziełach leksykograficznych.

\section{Toponimy w słownikach ogólnych języka polskiego XIX i XX wieku}

W SL i w SWil onimy stanowią stosunkowo duży zbiór jednostek leksykograficznych, należący do takich kategorii jak: imiona, nazwy bóstw i postaci mitycznych, a także nazwy mieszkańców państw, regionów i miast, które zaliczane są przez niektórych do strefy przejściowej między propriami a apelatywami [Rymut 2003: 9-10]. W słowniku Lindego pojawiają się ponadto nazwiska postaci historycznych typu Chodkiewicz. Natomiast w zakresie toponimów wspomniane dzieła odnotowują przede wszystkim: nazwy kontynentów jak: Afryka (SL, SWil), Ameryka (SL), Azja (SL, SWil), Europa (SL, SWil); nazwy krajów (cesarstw, królestw, księstw i arcyksięstw), np. Austria (SL, SWil), Brytania (SL), Egipt (SL), Francja (SL), Niemcy (SL, SWil), Rosja (SL, SWil), Szwecja (SL), Wegry (SWil); nazwy krain, prowincji lub ziem (czy ich części) przypisanych większym jednostkom geograficznym, np. Akwitania (SL), Mazowsze (SL), Mazury (SL), Podole (SL, SWil), Polska (SL, SWil), Ślask (SL), Wielkopolska (SL, SWil), Wotyń (SWil), Ukraina (SL, SWil), Małopolska (SL), a także nazwy miast, np. Babilon (SL, SWil), Kijów (SL, SWil), Kraków (SL), Królewiec (SL, SWil), Lwów (SL), Moskwa (SWil), Paryż (SL), Rzym (SL, SWil), Sodoma (SL, SWil), Toruń (SL, SWil), Warszawa (SL), Wilno (SL, SWil). Co ważne, ze względu na alfabetyczno-gniazdowy układ haseł w słowniku Lindego, nazwa własna może pojawić się wewnątrz artykułu hasłowego obejmującego dane gniazdo

${ }^{5}$ Konceptualizacja to „przetwarzanie przez umysł naszego doświadczenia rzeczywistości tak, że powstają konstrukty pojęciowe, które znajdują wyraz w znaczeniach leksykalnych” [Chłopicki (red.) 2006: 118]. 
słowotwórcze, np. ojkonim Lwów (wraz z derywatami lwowczyk, lwowianin, lwowski) występuje w haśle lwi, Wilno - w haśle *wilkopies, a Francja - w gnieździe rozpoczynającym się od czasownika francowacieć. Toponimy, jak też i inne typy nazw własnych, mogą być również wyrazami rozpoczynającymi dany artykuł hasłowy, uznanymi za wyjściowy dla określonego gniazda, tak jak np. nazwa Afryka dla wyrazów: Afrykanin, Afrykańczyk, Afer, Afryk, Afrykant, Afrykanka, afrykański, afrycki. Należy zaznaczyć, iż zarówno w SL, jak i w SWil obok użyć prymarnych, co ważne, w ramach tych samych haseł, odnotowywane są z rzadka użycia przenośne nazw własnych, zwłaszcza tych, które mają swoje źródła w Biblii czy mitologii greckiej lub rzymskiej. I tak, np. w SL w haśle Babilon czytamy: „iedno z naydawnieyszych mocarftw [...] w Azyi [...]. Ze kray ten i ftolica iego sławne przez budowanie wieży [...], przy którym zaszło pomieszanie ięzyków, [...] ztąd przenośnie: BABILON, BABILONIA, BABILOŃSKA wieża = nieład, zamieszanie, zamęt, odmęt".

Podobnie w SWil onimowi Babel przypisano trzy znaczenia: ,1) miasto Babilon, v. wieża Babel. 2) = fig. zamieszanie, zamęt, nieład. 3) = wybrakowane towary, brak". Zanotowano także użycie metonimiczne nazwy własnej. SWil podaje dla toponimu Moskwa dwa znaczenia: 1) 'państwo rosyjskie, lud moskiewski albo rosyjski' (znaczenie to poprzedzone jest kwalifikatorem: przenośnie) oraz 2) 'miasto stołeczne Rosji', co można interpretować jako odzwierciedlenie wzmożonej obecności takich użyć w ówczesnych tekstach, będącej najprawdopodobniej efektem rosyjskiego panowania na ziemiach polskich w XIX w.

Z kolei w SW nie notuje się zarówno toponimów, jak i żadnych innych typów jednostek onimicznych w ich użyciu prymarnym. Wyjątek stanowi onim Polak, definiowany jako: 1) 'człowiek urodzony w Polsce, obywatel polski' oraz 2) hut. 'młot podrzutowy zwykły we fryszerkach dawnych, polską metodą prowadzonych'. W SW uwzględnione zostały też jednostki Amerykanka, Anglik czy Fran$c u z$, lecz nie podano w nich znaczenia: mieszkaniec Ameryki, Anglii czy Francji. W SW notuje się zatem nazwy mieszkańców tylko wtedy, gdy występują one w znaczeniu zapelatywizowanym lub wchodzą w skład związków frazeologicznych. Podobna zasada jest stosowana wobec nazw własnych większych obszarów terytorialnych, np. hasło francja opatrzone jest komentarzem: wyraz ten używany jest w wyrażeniu narobić francji 'narobić krzyku, hałasu, bez skutku, dużo gadać, a mało robić'; jest synonimem wyrazu przymiot w znaczeniu 'syphylis'. W strukturze hasła podana jest także informacja, że leksem pochodzi od nazwy kraju Francja. Pokazuje to rodzącą się w leksykografii lingwistycznej tendencję do opracowywania słownictwa apelatywnego odrębnie od nazw własnych, która wywarła wpływ na kształt wielu słowników po 1945 r.

I tak w SJPD, podobnie jak w SW, nie uwzględnia się nie tylko toponimów, ale w zasadzie nie opisuje się odrębnie żadnych nazw własnych. Pojawiają się one jedynie (ale nie jest to reguła) jako element informacji uzupełniającej wewnątrz (zwykle na końcu) artykułów hasłowych takich wyrazów, które powstały: a) albo 
w wyniku derywacji słowotwórczej, np. w haśle bizantyjski odnajdujemy odwołanie do wyrazu podstawowego - nazwy własnej Bizancjum; b) albo w wyniku apelatywizacji ${ }^{6}$ jednostek onimicznych, np. w haśle sodoma po definicji 'o wielkim zamieszaniu, awanturze; o rozpuście' i cytatach zamieszczona jest nota o onimie bazowym ${ }^{7}$ (,Sodoma, miasto w Palestynie, według Biblii ukarana za rozpustę ogniem z nieba") wskazująca na te cechy konotatywne nazwy własnej, które doprowadziły do powstania nowej jednostki leksykalnej. Wyjątek stanowią nazwy mieszkańców, odnotowywane w SJPD wówczas, gdy równolegle z nimi funkcjonują w języku wyrazy pospolite (pochodne od onimów i mające ten sam kształt formalny co onim bazowy), np. nazwa Hiszpanka 'kobieta narodowości hiszpańskiej' umieszczona jest na pierwszym miejscu w haśle hiszpanka, które ma trzy znaczenia: 'grypa', 'bródka na szpic' i 'tabaka hiszpańska'. Podobnie rozwiązany został problem opisu nazw własnych w SJPSz.

Natomiast w leksykografii najnowszej z jednej strony kontynuuje się opisany powyżej sposób dobierania haseł. Na przykład w SWJP nie rejestruje się żadnych nazw własnych, podaje się je tylko po w poszczególnych artykułach hasłowych leksemów będących rezultatem apelatywizacji w formie komentarza typu: od nazwy kraju X/miasta X/krainy X/portu X. W ten sposób opracowano m.in. takie leksemy i wyrażenia pochodne od toponimów, jak: angora, arkadia, boston, charleston, gouda, hamburger, kaszmir, koniak, madera, malaga, mokka, panama, sodoma i gomora, tokaj. Z kolei w ISJP wprowadza się jako oddzielne hasła tylko nazwy mieszkańców państw, regionów i miast. Z drugiej strony w polskiej leksykografii ujawnia się przeciwstawna tendencja, polegająca na opisywaniu coraz to większej liczby nazw własnych i rozmaitych ich typów. I tak, najwięcej i najbardziej zróżnicowanych jednostek onimicznych pojawia się w PSWP i USJP. W pierwszym z wymienionych słowników odnajdujemy przede wszystkim nazwy kontynentów, a ponadto bardzo rozbudowany zbiór nazw mieszkańców oraz wszelkich eponimów. Na przykład obok hasła Europa (definiowanego jako: „1. geograficzny 'kontynent położony na północ od równika na obu półkulach [...] ściśle połączony z Azją...', 2. potoczny 'poziom kultury spożycia, zaopatrzenia sklepów itp. zbliżony do standardu zachodnioeuropejskiego' ") opracowane zostały następujące onimy wtórne: derywaty semantyczne, jak i strukturalno-semantyczne utworzone od omawianego onimu bazowego, czyli: europa (środowiskowy 'opakowanie szklane o pojemności 0,5 litra'), europ (chemiczny 'pierwiastek chemiczny'), europeida ('osoba, która reprezentuje białą rasę człowieka'), europeizm, Europejczyk $(\rightarrow$ Europejka), europejski $(\rightarrow$ europeistyka, europeizacja, europejskość,

${ }^{6}$ Przyjmujemy za M. Rutkowskim, że apelatywizacja to proces ustanowienia się nowej jednostki leksykalnej w postaci apelatywu deonimicznego. „Apelatywizacja następuje, gdy metafora nazewnicza ulega konwencjalizacji poprzez «upowszechnienie» czy wysoką frekwencję użycia" [Rutkowski 2007: 247-248].

${ }^{7}$ Przez onim bazowy rozumiemy za B. Dereń „każde imię własne, będące podłożem i budulcem derywatów zarówno strukturalnych, jak i semantycznych" [Dereń 2005: 19]. 
europeizowanie $\rightarrow$ europeizowanie się, europeizować $\rightarrow$ europeizować się). Należy zaznaczyć, iż typowe dla PSWP jest to, że w sytuacji, gdy dana nazwa własna nie jest odnotowana jako odrębne hasło, a pojawia się ona w definiensie jakiegoś leksemu, który jest od niej derywowany, wówczas definiens wyrazu pochodnego zawiera definicję onimu bazowego. Dzięki temu z jednej strony unika się błędu ignotum per ignotum, ale $\mathrm{z}$ drugiej - zbytnio rozbudowuje definicję informacjami encyklopedycznymi. Przykładem zastosowania tej metody jest hasło Galicjanin, w którym znaczenie ujęto w następujący sposób: „osoba mieszkająca w Galicji albo pochodząca z Galicji - dawnej części ziem Rzeczpospolitej Polskiej znajdującej się pod zaborem austriackim w latach 1772-1918, a obejmującej południową część województw krakowskiego i sandomierskiego, niemal całe województwo ruskie, część bełzkiego i Podole, po trzecim rozbiorze ziemie aż po linię Pilicy, środkowej Wisły i Bugu, a po 1846 r. także Rzeczpospolitą Krakowską albo geograficznej krainy leżącej na terytorium Hiszpanii”.

Toponimy, w szczególności zaś: nazwy kontynentów, państw, regionów, krain, miast, występują w USJP jako odrębne hasła, np Azja, Akwitania, Afganistan, Białostocczyzna, Bielskie, Budziszyn. Jak podano we Wstępie do tego słownika, uwzględnia się w nim: nazwy własne, rodzime i zaadaptowane pochodzenia obcego, takie jak: 1. wyrazy pojedyncze, np. Austria, Ślask, Dolny Ślask, Praga; 2. wyrazy złożone: 2a. formacje, np. Babimojszczyzna, Lwowskie, Polak, Polska, Warszawa; 2b. kompozycje, np. Antigua i Barbuda, Biatystok, Białoruś, Wielka Brytania; 3. skrótowce, np. NRD, RFN, RP, USA, ZSRR; 4. derywaty od nazw własnych, np. londyńczyk, paryski, warszawianin. W USJP zarówno nazwy wyjściowe (onimy bazowe), jaki i ich derywaty semantyczne - nazwy zapelatywizowane ujęte są w ramach jednego artykułu hasłowego, np. „Calvados 1. «region i kraina historyczna w północnej Francji» 2. calvados kulin. a) «francuska wódka o brązowym zabarwieniu, produkowana z jabłek; winiak jabłkowy» ○ Wytwórnia calvadosów; b) «porcja tej wódki» ○ Wypić dwa calvadosy. ○ Kieliszek calvadosu a. calvadosa".

Ponadto jednym z elementów mikrostruktury omawianego słownika jest pole - relacje semantyczne, które wypełnia się także w wypadku nazw własnych (nawet ich użyć prymarnych), np. dla nazwy Stany Zjednoczone 'państwo w Ameryce Północnej' podano takie relacje semantyczne, jak: hiperonim: państwo, synonimy: Ameryka, Stany, USA, Wuj Sam oraz meronim: Dziki Zachód.

\section{Propozycja leksykograficznego opisu nazw własnych}

O tym, co ze zbioru nazw własnych i wyrazów od nich tworzonych winno stać przedmiotem opisu w słownikach ogólnych języka polskiego, pisał już K. Rymut [1988: 121-122]. Odwołując się do propozycji badacza, twierdzimy, iż w zakresie toponimów do opisu w słowniku należy zakwalifikować: 
1) toponimy (czyli: choronimy, ojkonimy, hydronimy, oronimy, urbanonimy oraz ekonimy), które są podstawą apelatywów deonimicznych typu: Mekka (ponieważ funkcjonuje apelatyw mekka);

2) toponimy występujące $w$ tekstach $w$ metonimicznych i/lub metaforycznych użyciach wtórnych, np. Szwajcaria a) 'państwo', b) 'mieszkańcy', c) 'władze', d) 'państwo dobrobytu', e) 'malownicze miejsce';

3) toponimy będące składnikami idiomów, przysłów czy skrzydlatych słów typu: Kraków (ponieważ występuje frazeologizm Nie od razu Kraków zbudowano);

4) toponimy, które stanowią podłoże derywatów słowotwórczych, np. nazw mieszkańców, przymiotników od nazw miejscowych (ich uwzględnienie jest konieczne w celu uniknięcia błędu ignotum per ignotum, który pojawia się, gdy w definicji danego derywatu użyta jest nazwa własna, lecz nie definiuje się jej w słowniku); jeśli na projektowanej liście haseł do danego słownika są np. leksemy typu: Chińczyk, polski, taternik, to powinny być jednocześnie opracowane hasła: Chiny, Polska, Tatry);

5) derywaty słowotwórcze, których podstawy stanowią toponimy: a) nazwy mieszkańców i narodowości typu: Afrykanin, Afrykanka, krakus, krakuska, Krakus, Krakuska; b) inne derywaty słowotwórcze typu: warszawka, europejskość, polski, po krakowsku, zamerykanizować;

6) toponimy przeniesione, ale tylko wówczas, jeśli na projektowanej liście haseł znajdzie się nazwa własna będąca nominatem pierwotnym i jeśli znajdziemy wystarczająco częste potwierdzenie używania nazwy przeniesionej w analizowanych tekstach, np. Wenecja 'wieś w Polsce'.

Z kolei budowa artykułu hasłowego dla danego onimu nie powinna różnić się znacząco od budowy hasła dla wyrazu pospolitego. Idealna mikrostruktura mogłaby zawierać następujące elementy:

1) wyraz hasłowy;

2) informację o możliwych zapisach ortograficznych (poświadczonych w tekstach);

3) informację o pochodzeniu (ściślej o „wariancie obcojęzycznym” dla spolszczonych nazw własnych);

4) kwalifikator;

5) definicję;

6) ilustrację materiałową: a) kolokacje (typowe i częste połączenia wyrazowe, osobne dla każdego ze znaczeń), b) cytaty;

7) relacje semantyczne (przypisane poszczególnym znaczeniom), w jakie wchodzą onimy zarówno z innymi onimami, jak i apelatywami (synonimia, antonimia, hiperonimia, hiponimia, meronimia);

8) informację fleksyjną;

9) informację składniową;

10) derywaty słowotwórcze (opracowane w słowniku jako odrębne hasła);

11) związki frazeologiczne i przysłowia zawierające dany onim. 
Zaznaczmy, iż taki opis jednostek onimicznych byłby możliwy przede wszystkim w elektronicznym wydaniu słownika. W związku z tym, iż we wcześniejszych rozważaniach uznano, że nazwy własne znaczą, skupimy się w dalszej części na omówieniu propozycji opisu w słowniku struktury znaczeń danego onimu oraz sposobu definiowania zwłaszcza onimu bazowego. Odwołując się do ustaleń B. Dereń [2005] i M. Rutkowskiego [2007], przyjmujemy, że idealna (maksymalna) struktura znaczeń danej nazwy własnej mogłaby wyglądać w słowniku w sposób następujący:

1) znaczenie onimu bazowego (kategorialne minimum znaczeniowe + cechy desygnacyjne, uwzględniające jedynie konieczne informacje encyklopedyczne);

2) znaczenie metonimiczne onimu wtórnego ${ }^{8}$ (tożsamego formalnie $\mathrm{z}$ onimem bazowym); w wypadku toponimów najczęściej występują przesunięcia semantyczne typu [zob. też: Dereń 2005: 44-50; Rutkowski 2007: 100-107]: a) 'miejsce (kontynent, region, kraina)' $\rightarrow$ 'władze tego miejsca' $\rightarrow$ 'mieszkańcy', np. Afryka, Śląsk; b) 'państwo' $\rightarrow$ 'władze (rząd) tego państwa' $\rightarrow$ 'mieszkańcy' $\rightarrow$ 'drużyna sportowa (sportowcy) reprezentująca to państwo', np. Polska; c) 'miasto będące stolicą' $\rightarrow$ 'władze państwa, którego stolicą jest to miasto' $\rightarrow$ 'władze tego miasta' $\rightarrow$ 'mieszkańcy' $\rightarrow$ 'drużyna sportowa (sportowcy) reprezentująca to miasto', np. Warszawa; d) 'miasto' $\rightarrow$ 'władze' $\rightarrow$ 'drużyna sportowa (sportowcy) reprezentująca to miasto', np. Kraków; e) 'miejscowość' $\rightarrow$ 'instytucja', np. Genewa; f) 'budynek (siedziba władzy)' $\rightarrow$ 'przedstawiciel władzy', np. Biały Dom; g) 'miejscowość' $\rightarrow$ 'spotkanie dyplomatyczne, polityczne etc.' $\rightarrow$ 'postanowienia, jakie zapadły w trakcie tego spotkania', np. Jałta lub szerzej [za: Rutkowski 2007: 106]: 'miejscowość' $\rightarrow$ 'efekt (rezultat) wydarzenia', np. Katyń;

3) znaczenie metaforyczne onimu wtórnego (tożsamego formalnie z onimem bazowym);

4) znaczenie nazwy przeniesionej (na inne obiekty, takie jak: miasto, wieś, obiekt terenowy itp.).

Co ważne, między poszczególnymi znaczeniami tak opisanej nazwy własnej (jako jednostki polisemicznej) istnieją, zgodnie z myślą J. Apresjana, „takie poziomy opisu semantycznego, na których ich definicje lub konotacje mają «nietrywialną» część wspólną" [Apresjan 1980: 72-73]. Jeśli więc między znaczeniem onimu bazowego a znaczeniem metaforycznym nie ma podobieństwa, wówczas mamy do czynienia z homonimem, czyli nową jednostką (apelatywem deonimicznym), zapisywaną konwencjonalnie małą literą, która opisywana jest $\mathrm{w}$ od-

${ }^{8}$ Przyjmujemy rozumienie szersze niż B. Dereń [2005: 15]. Uznajemy za onimy wtórne zarówno derywaty semantyczne tożsame formalnie z nazwą własną (onimem bazowym), od której zostały utworzone, powstałe na podłożu użyć metonimicznych i metaforycznych, jak i skonwencjonalizowane określenia peryfrastyczne, które B. Dereń odróżnia od onimów wtórnych i określa jako nominaty wtórne. Do onimów wtórnych zaliczane są także pochodne od nazw własnych derywaty słowotwórcze, które nie wchodzą w zakres rozważań. 
rębnym artykule hasłowym ${ }^{9}$. Uznajemy także, że nie ma konieczności podawania w definiensie onimu bazowego rozbudowanej informacji encyklopedycznej, jak też informacji o jego wartościach konotacyjnych. Po pierwsze - dlatego że ogólną definicję onimu bazowego mogą uzupełnić i doprecyzować szczegółowo opracowane kolokacje. Po drugie - jeśli chcemy opisywać jednostki onimiczne na równi $\mathrm{z}$ apelatywami, to należy zauważyć, że w słownikach ogólnodefinicyjnych nie wyróżnia się cech konotacyjnych, prezentując tzw. znaczenie podstawowe jednostki, po to, by pokazać na przykład, w jaki sposób doszło do przeniesienia znaczenia $\mathrm{w}$ procesie metaforyzacji ${ }^{10}$. Cechy konotacyjne danej nazwy własnej mogą i powinny być uwzględnione jako odrębne znaczenia (podhasła) danej nazwy własnej, ale wówczas, gdy znajdziemy dla nich poświadczenie w tekstach. Niektóre z konotacji ujawniają się bowiem dopiero w użyciach nie onimów bazowych, lecz wyrazów pochodnych od nich słowotwórczo. Przyjrzyjmy się zatem, jak wyglądałaby w słowniku struktura znaczeniowa hasła Szwecja wraz z ilustracją materiałową. Tak jak wspomniano wcześniej, proponowany tu sposób opisu znaczeń mógłby być zastosowany głównie w elektronicznym słowniku ogólnodefinicyjnym.

\section{WYRAZ HASLOWY: Szwecja 1. ZNACZENIE ONIMU BAZOWEGO}

DEFINICJA: 'miejsce - państwo w północnej części Europy'

KOLOKACJE:

- centralna, poludniowa, pótnocna, sąsiednia, środkowa, wschodnia, zachodnia; zimna; wspótczesna; bogata; liberalna, neutralna, opiekuńcza, socjalistyczna; luterańska, protestancka; rodzinna Szwecja;

- Szwecja lat czterdziestych (pięćdziesiatych...); Szwecja w czasie bezkrólewia; w latach osiemdziesiatych; Szwecja i Austria, Szwecja i Belgia, Szwecja i Dania, Szwecja i Finlandia, Szwecja i Holandia, Szwecja i Irlandia, Szwecja i Luksemburg, Szwecja i Niemcy, Szwecja i Norwegia, Szwecja i Polska, Szwecja i Rosja, Szwecja i Szwajcaria, Szwecja i Ukraina, Szwecja i USA, Szwecja i Wielka Brytania, Szwecja i Włochy;

- brzeg, granice, poludnie, pótnoc, teren, terytorium, wody terytorialne, wybrzeże; stolica; królestwo; ambasada; ambasador, król, królowa, premier, rząd, władze; mieszkańcy, obywatel, obywatelka; drużyna, mistrz, reprezentacja; historia; barwy Szwecji; droga, lot, podróż, powrót, rejs, wycieczka, wyjazd; prom, samolot; eksport do Szwecji; powrót; artysta, naukowcy, przyjaciele ze Szwecji; wojna ze Szwecja; pobyt, praca, życie; festiwal, występ w Szwecji;

- Szwecja leży gdzieś; jest jakimś krajem; utraciła Finlandię (pozycję mocarstwa ...); weszła do Unii Europejskiej;

9 Jest to umowne. Wystarczy, iż uznamy, że w słowniku przyjmuje się wyróżnianie tylko homonimii leksykalno-gramatycznej, a tym samym nie będziemy mieć podstaw do ujmowania w odrębnych hasłach jednostek typu Targowica 'miejscowość', targowica 'zdrada narodowa'. Jedynym problemem, który wówczas pozostałby do rozwiązania, byłoby to, w jaki sposób techniczny zaznaczyć i podać informację o różnicy w ortografii.

${ }^{10} \mathrm{~Np}$. w definicji leksemu świnia przy opisie tzw. znaczenia podstawowego, zarówno w SJPD, SWJP, jak i w USJP czy ISJP nie znajdziemy informacji, że jest to zwierzę brudne, które dużo, łapczywie i niechlujnie je, lecz opis cech desygnacyjnych, chociaż wymienione konotacje posłużyły do powstania wyrażeń typu: jeść jak świnia lub zachowywać się jak świnia, opisanych w ramach dalszych podhaseł słownikowych jako znaczenia pochodne. 
- odwiedzić/odwiedzać, zwiedzić; opuścić; reprezentować (w mistrzostwach...); zaatakować Szwecję; (most) tączacy Szwecję z Dania (z Norwegia); jakiś obszar (część czegoś) przypadt Szwecji; jechać, jeździć, lecieć, płynąć, pojechać, popłynąć, przyjechać, uciec/uciekać, wrócić/wracać, wyemigrować, wyjechać/wyjeżḋać do Szwecji; przyjechać, wrócić/wracać; pochodzić ze Szwecji; mieszkać, pracować, przebywać, zamieszkać, zostać, żyć w Szwecji.

\section{CYTATY:}

1. „Sztokholm jest wielkim miastem, ale jednocześnie miejscowością wczasową. W promieniu kilkudziesięciu kilometrów znajduje się ok. 24 tys. wysp i wysepek rozłożonych na wodach Bałtyku i wlewającego się do niego jeziora Melar. Dlatego stolica Szwecji jest nazywana Wenecją Północy”. NKJP: Tomasz Walata, Szwecja: ogród szkierów, „Polityka”, 21. 07.2007.

2. „Szwecja jest krajem ubogim w surowce, o trudnym i czasem niesprzyjającym klimacie”. NKJP: (maj), O wierzbie energetycznej, „Gazeta Krakowska”, 11.12.2002.

\section{2a. ZNACZENIE METONIMICZNE ONIMU WTÓRNEGO}

DEFINICJA: 'władze Szwecji'

KOLOKACJE:

- neutralna Szwecja;

- kontakty, rokowania ze Szwecja; ugoda, umowa, zgoda między Szwecją a Dania...;

- Szwecja opodatkowata coś; podpisała konwencje (traktat, rozejm ...), zawarta rozejm (pokój, układ) z kimś/gdzieś; wprowadziła jakiś podatek, (jakiś przepis, zakaz czegoś); zobowiązata się robić coś; żada czegoś; reprezentować Szwecję (w negocjacjach...);

- podpisać pokój (rozejm, traktat, umowę), zawrzeć rozejm (przymierze, sojusz) ze Szwecja.

\section{CYTATY:}

1. „5 grudnia 1705 r. podpisał jako komisarz ze strony Stanisława Leszczyńskiego traktat ze Szwecją i wycofał się z życia politycznego". NKJP: Andrzej Ćmiech, Polska mogła mieć króla z Gorlic, „Gazeta Krakowska”, 13.07.2007.

2. „Wielka Brytania, Dania, Holandia, Irlandia i Szwecja zobowiązały się, że od początku polskiego członkostwa będą bez przeszkód przyjmować do pracy Polaków”. NKJP: Dariusz Zalega, To jest gra o wszystko, „Trybuna Śląska”, 13.12.2002.

\section{2b. ZNACZENIE METONIMICZNE ONIMU WTÓRNEGO}

DEFINICJA: 'mieszkańcy Szwecji'

KOLOKACJE:

- bogata; liberalna; luterańska, protestancka Szwecja;

- kontakty ze Szwecja;

- (cała) Szwecja czeka na coś, emocjonowała się czymś, jest w szoku, pamięta o czymś, pasjonowała się czymś, uczciła pamięć kogoś, żyje czymś;

- wstrzasnąć; rządzić Szwecją.

\section{CYTATY:}

1. „Dla narciarzy Bieg Wazów jest wielkim sportowym przeżyciem, dla Szwecji - świętem. [...] Niemal cała Szwecja żyje tym wydarzeniem”. NKJP: Zygmunt Ostapiuk, Stefan Leniowski, Nowotarżanin w Biegu Wazów, „Tygodnik Podhalański”, listopad 1996.

2. „Morderstwo wstrząsnęło Szwecją i jest od wielu dni głównym tematem dyskusji medialnej, rozmów na ulicy i w mieszkaniach”. NKJP: Tomasz Walat, Honor Kurda, „Polityka”, 16.02.2002. 


\section{2c. ZNACZENIE METONIMICZNE ONIMU WTÓRNEGO}

DEFINICJA: 'drużyna sportowa reprezentująca Szwecję'

KOLOKACJE:

- silna Szwecja;

- Szwecja w eliminacjach, w finale; Szwecja i Anglia, Szwecja i Belgia, Szwecja i Butgaria ...;

- zwycięstwo Szwecji; mecz Szwecji z Holandia (Polska...); mecz, spotkanie, występ przeciwko Szwecji; zwycięstwo nad Szwecja; mecz, pojedynek, spotkanie ze Szwecja;

- Szwecja gra z Czechami...; pokonała Finlandię (Polskę...), rozgromita Butgarię (Danię...), wygrała z Holandia (z Wegrami...), zwyciężyla Stowenię.../z Austria ...; awansowata do finału (do pólfinału...); zremisowata; przegrała z Łotwa (Portugalia...), odpadła w finale (pólfinale...); zajęta któreś miejsce;

- pokonać, rozgromić, wyeliminować Szwecję; grać, zagrać; wygrać; zremisować; przegrać ze Szwecją.

\section{CYTATY:}

1. „Na stadionie w Chorzowie, w eliminacyjnym meczu mistrzostw Europy, Polska przegrała ze Szwecją 0:1”. NKJP: Kuba Stanilewicz, Zawiedli, „Dziennik Bałtycki”, 01,04.1999.

2. W ostatnich meczach kontrolnych Szwecja pokonała Słowację 3:2". NKJP: (PG), Kto faworytem?, „Gazeta Krakowska”, 25.04.2003.

\section{ZNACZENIE METAFORYCZNE ONIMU WTÓRNEGO}

DEFINICJA: 'państwo dobrobytu, które ma rozwinięty system opieki socjalnej przy wysokich podatkach'

\section{KOLOKACJE:}

- druga Szwecja

CYTATY:

1. „Z marketingowego punktu widzenia lewica nie powinna zaproponować właśnie drugiej Szwecji? Jest to również popularny kierunek emigracji, a i polityka skandynawska znacznie bliższa waszym poglądom? Nawet padło już takie hasło, że Lewica i Demokraci zaproponuje Polakom Szwecję, jeśli Platforma zaproponuje Irlandię". NKJP: Strona Marka Borowskiego, www.borowski.pl, Internet.

2. „Przy założeniu, że W. Brytania jest obecnie państwem socjalnym, to Polska przy takim udziale podatków powinna być drugą Szwecją albo Norwegią". NKJP: Forum Stanistawa Michatkiewicza, www.forum.michalkiewicz.pl, Internet.

\section{ZNACZENIE METAFORYCZNE ONIMU WTÓRNEGO}

DEFINICJA: 'państwo, w którym funkcjonuje bardzo surowe dla opiekunów prawo dotyczące przemocy w rodzinie'

\section{KOLOKACJE:}

- druga Szwecja

\section{CYTATY:}

1. „Poczekaj, jak tu zrobią drugą Szwecję, to nawet paluszkiem nie pogrozisz”. NKJP: Bardzo nerwowe dziecko - pomocy, Usenet -- pl.soc.dzieci, Internet.

2. „Ten zapis dotyczy rzeczywistej przemocy, nie sytuacji, w której ludzie się pokłócą. Nie planujemy drugiej Szwecji, gdzie to poszło za daleko - obiecuje Guzowska". NKJP: (domi) tvn, Kto ma prawo odebrać dziecko? Spór o ustawę, „Gazeta Pomorska”, 2.03.2010. 
Jak pokazuje powyższy przykład, nazwy własne posiadają zdolność wyznaczania kategorii obiektów, do których się odnoszą. Onim Szwecja w swym użyciu prymarnym zawiera bowiem minimum znaczeniowe, które możliwe jest do zinterpretowania i zdefiniowania na podstawie analizy kolokacji wskazujących, że mamy do czynienia z jakimś miejscem (zob. m.in. centralna, południowa, pótnocna, sąsiednia Szwecja; brzeg, granice, teren, terytorium, wody terytorialne, wybrzeże Szwecji), a ściślej - państwem (zob. m.in. stolica; królestwo; ambasada; ambasador, król, królowa, premier, rzad, władze; mieszkańcy, obywatel, obywatelka). Komentarza wymaga także problem opisu regularnych przesunięć semantycznych (typu 'państwo' $\rightarrow$ 'władze' $\rightarrow$ 'mieszkańcy'). Zdaniem niektórych badaczy, w tym M. Grochowskiego czy R. Grzegorczykowej, polisemia systemowa stanowi przykład wariancji tekstowej, która nie powinna być przedmiotem opisu w słowniku, gdyż znaczenia wariantowe mogą być doraźnie $\mathrm{w}$ tekstach wprowadzane i swobodnie odczytywane na podstawie kontekstu i sytuacji przez odbiorcę znającego pewne reguły przesunięć znaczeniowych [Bednarek, Grochowski 1997; Grzegorczykowa 1990]. Argument o całkowitej regularności danego typu przesunięcia metonimicznego można łatwo obalić, gdyż wystarczy zbadać użycia tekstowe choćby takich toponimów, jak Warszawa i Moskwa. W tekstach z NKJP odnajdujemy systematyczne, wtórne użycia metonimiczne nazwy własnej Warszawa, takie jak: 'władze państwa' $\rightarrow$ 'władze miasta' $\rightarrow$ 'mieszkańcy' $\rightarrow$ 'drużyna sportowa'. Z kolei w wypadku użyć nazwy Moskwa nie ma poświadczenia dla regularnego przesunięcia typu 'miasto' $\rightarrow$ 'władze miasta'. Przychylamy się więc do poglądów P. Żmigrodzkiego, którego zdaniem „odnotowywanie wszystkich znaczeń dających się zinterpretować jako efekt regularnej polisemii w każdym haśle słownikowym jest uzasadnione, pozwala bowiem wyłonić jednostki, dla których rzeczywiście te znaczenia się realizują oraz te, dla których pozostają one tylko potencją" [Żmigrodzki 2008: 150].

\section{Podsumowanie}

Stoimy na stanowisku, że nazwy własne, w tym toponimy, należy opisywać w słownikach ogólnodefinicyjnych z kilku powodów. Po pierwsze - dlatego że znaczą i że analizując użycia tekstowe (co ilustrują wybrane przykłady kolokacji dla jednostki Szwecja), jesteśmy w stanie zarówno orzec, do jakiej nadrzędnej kategorii pojęciowej ('miejsce', 'mieszkańcy', 'osoba' etc.) odwołuje dana nazwa, jak i zinterpretować różnego rodzaju użycia wtórne (metonimiczne i metaforyczne). Po drugie - uwzględnianie onimów w szerokim zakresie pozwala uniknąć sytuacji, kiedy to $\mathrm{w}$ definiensie jakiegoś derywatu słowotwórczego (utworzonego od nazwy własnej) pojawia się onim bazowy nieuwzględniony w danym słowniku 
(w efekcie mamy błąd ignotum per ignotum) lub też definicja derywatu zawiera informacje o onimie bazowym, a przez to jest zbyt rozbudowana i encyklopedyczna. Po trzecie zaś - leksykografia winna odpowiadać na oczekiwania użytkowników języka, a jednym z nich jest właśnie obecność nazw własnych w filologicznych słownikach definicyjnych.

\section{Wykaz skrótów}

ISJP - Bańko Mirosław (red.), 2000, Inny słownik języka polskiego, Warszawa.

PSWP - Zgółkowa Halina (red.), 1994-2005, Praktyczny słownik współczesnej polszczyzny, Poznań.

SJPD - Doroszewski Witold (red.), 1958-1969, Słownik języka polskiego, Warszawa.

SJPSz - Szymczak Mieczysław (red.), 1994, Stownik języka polskiego, Warszawa.

SL - Linde Samuel Bogumił, 1807-1814, Stownik języka polskiego, Lwów.

SW - Karłowicz Jan, Kryński Adam, Niedźwiedzki Władysław (red.), 1900-1927, Słownik języka polskiego, Warszawa.

SWil -Zdanowicz Aleksander et al. (red.), 1861, Słownik języka polskiego, Wilno.

SWJP - Dunaj Bogusław (red.), 1996, Słownik współczesnego języka polskiego, Warszawa.

USJP - Dubisz Stanisław (red.), 2004, Uniwersalny słownik języka polskiego, Warszawa.

\section{Bibliografia}

Algeo John, 1973, On defining the proper names, Gainesville.

Apresjan Jurij D., 1980, Semantyka leksykalna. Synonimiczne środki języka, Wrocław.

Bartmiński Jerzy, 2007, Językowe podstawy obrazu świata, Lublin.

Bartmiński Jerzy (red.), 1993, O definicjach i definiowaniu, Lublin.

Bednarek Adam, Grochowski Maciej, 1997, Zadania z semantyki językoznawczej, Toruń.

Bogusławski Andrzej, 1977, O interpretacji zdań z wyrażeniami okazjonalnymi, „Przegląd Humanistyczny" 2, 39-56.

Chlebda Wojciech, 2000, Ile jest Mławy w Mławie? Pochodne nazw własnych w językowym obrazie świata Polaków, „Język a Kultura”, t. 13, red. A. Dąbrowska, J. Anusiewicz, Wrocław, 247-259.

Chłopicki Władysław (red.), 2006, Kognitywizm i komunikatywizm. Dwa bieguny współczesnego językoznawstwa - dyskusja przy okragtym stole, Kraków.

Cieślikowa Aleksandra, 1993, Leksykografia nazw własnych a leksykografia nazw pospolitych, [w:] Władysław Lubaś, Franciszek Sowa (red.), Wokół słownika współczesnego języka polskiego III, Kraków, 23-31.

Cieślikowa Aleksandra, 2006, Onimizacja, apelatywizacja i derywacja, [w:] Zofia Abramowicz, Elżbieta Bogdanowicz (red.), Onimizacja i apelatywizacja, Białystok, 47-56.

Dereń Bożena, 2005, Pochodne nazw własnych w słowniku i w tekście, Opole.

Grochowski Maciej, 1993, Konwencje semantyczne a definiowanie wyrażén językowych, Warszawa. Grzegorczykowa Renata, 1990, Wprowadzenie do semantyki językoznawczej, Warszawa.

Kaleta Zofia, 1998, Teoria nazw własnych, [w:] Ewa Rzetelska-Feleszko (red.), Polskie nazwy własne. Encyklopedia, Warszawa-Kraków, 15-36.

Kosyl Czesław, 1983, Forma i funkcja nazw własnych, Lublin. 
Kuryłowicz Jerzy, 1956, La position linguistique du nom propre, „Onomastica” II, 1-14.

Langacker Ronald, 1995, Wykłady z gramatyki kognitywnej, Lublin

Lubaś Władysław, 2003-2004, Wyraz, leksem i syntagma w nazwach własnych, „Folia onomastica Croatica" $12-13,323-330$.

Mill John Stuart, 1843, A system of logic, London.

NKJP: Narodowy Korpus Języka Polskiego, www.nkjp.pl.

Przepiórkowski Adam, Bańko Mirosław, Górski Rafał L., Lewandowska-Tomaszczyk Barbara (red.), 2012, Narodowy Korpus Języka Polskiego, Warszawa.

Rutkowski Mariusz, 2001 (2002), Wstęna charakterystyka funkcji nazw własnych, „Onomastica” XLVI, 7-29.

Rutkowski Mariusz, 2007, Nazwy wtasne w strukturze metafory i metonimii, Olsztyn.

Rymut Kazimierz, 1988, Nazwy własne w słowniku współczesnego języka polskiego, [w:] Władysław Lubaś (red.), Wokót słownika wspótczesnego języka polskiego, Wrocław, 117-123.

Rymut Kazimierz, 2003, Granica czy strefa przejściowa między nomen appallativum a nomen proprium?, [w:] Kazimierz Rymut (red.), Szkice onomastyczne i historycznojęzykowe, Kraków, 9-12 [przedruk z 1979].

Rzetelska-Feleszko Ewa, 1993, Nazwy własne, [w:] Jerzy Bartmiński (red.), Współczesny język polski. Encyklopedia kultury polskiej XX wieku, t. 2, Wrocław, 397-402.

Šramék Rudolf, 1999, Úvod do obecné onomastyki, Brno.

Taylor John Robert, 2007, Gramatyka kognitywna, Kraków.

Tokarski Ryszard, 1988, Konotacja jako sktadnik treści słowa, [w:] Jerzy Bartmiński, Ryszard Tokarski (red.), Profilowanie w języka i w tekście, Lublin, 35-54.

Tokarski Ryszard, 1991, Poziomy konotacji semantycznej, „Język a Kultura”, t. 2, red. J. Puzynina, J. Bartmiński, Wrocław, 45-52.

Żmigrodzki Piotr, 2008, Stowo - stownik - rzeczywistość. Z problemów leksykografii i metaleksykografii, Kraków.

Patrycja Pałka

\section{Toponyms in general Polish dictionaries}

(Summary)

In the following article, the author wants to answer the question of whether and in what way names - based on examples of toponyms - should be described in the general dictionaries of the Polish language. The problem of the description of onimistic units within the linguistic lexicography is not a new problem, but the one already dealt with on numerous occasions, for example, in the work of Kazimierz Rymut [1988], Aleksandra Cieślikowa [1993], Wojciech Chlebda [2000] and Bożena Dereń [2005]. However, this problem is still valid and current. The issue of the validity of those increasingly problematic aspects of the language is failure to provide a coherent concept for names - description within the non-onomastic and non-specialist lexicographical works, which is directly influenced by the fact that these units are being omitted in most dictionaries. Consequently, one of the first aspects which needs to be taken into consideration when planning action is the presentation of the stance taken to deal with the problem of semantic values nomina propria and the discussion about the presence of toponyms in selected 19th and 20th-century 
dictionaries. Then the proposition of the description concept of the lexicographic names is presented, based on selected toponyms, which on the one hand, draws on the research in the field of linguistics and semantics onomastics, and on the other hand is a direct outcome of the analysis of the texts collected in the National Corpus of the Polish Language.

Słowa kluczowe: toponimia, leksykografia, semantyka, mikro- i makrostruktura słownika, metafora, metonimia.

Key words: toponymy, lexicography, semantics, micro- and macrostructure of a dictionary, metaphor, metonymy. 